Acta vet. scand. 1961, 2, 103-119.

From the Veterinary College of Norway, Department of Internal Medicine, Oslo.

\title{
STUDIES ON ALTERATIONS IN THE RUMEN FLUID OF SHEEP, ESPECIALLY CONCERNING THE MICROBIAL COMPOSITION, WHEN READILY AVAILABLE CARBO- HYDRATES ARE ADDED TO THE FOOD III. STARCH
}

By

Nils Kro.gh.

In earlier publications (Krogh 1959, 1960) data were presented on results obtained when sucrose or lactose was given in excess to hay-fed sheep. It was apparent from these feeding experiments that, on the whole, the two sugars induced similar alterations in the rumen population accompanied by an acute acid indigestion. The most characteristic microbial changes appeared to be a transient rise in the streptococcal flora followed by the development of a rumen lactobacillosis with depression and destruction of the normal flora and fauna. It was further found that the tolerance for lactose was somewhat higher than for sucrose.

The feeding experiments reported in the present paper were conducted to gain information on the effect of starch upon the rumen population and to compare this effect with that obtained when sucrose and lactose were given under similar conditions.

Regarding the influence of starch-rich rations on the rumen digestion considerable research work has been carried out in recent years, although less frequently concerned with the microbial alterations occurring in the rumen. In feeding experiments with calves Pounden and Hibbs (1948) found a rise in the protozoal concentration when some grain was added to a hay diet 
followed by a reduction when the proportion of grain in the ration was increased further. Simultaneously, the bacterial flora did also change, small Gram-positive rods or cocci being observed in increasing amounts. Similar observations were made by Gall and Huhtanen (1951) and they reported that the concentration of Gram-positive cocci in the rumen increased directly in proportion to the amount of grain fed, whereas Masson (1950) observed large numbers of Clostridium butyricum in the rumen of sheep fed a ration rich in flaked maize. Further, in feeding experiments with sheep Williams et al. (1953) observed a highly significant reduction in the rumen bacterial counts as well as a marked change in the types of organisms present when starch was added to a low protein diet. The change in the bacterial flora was characterized by an increased proportion of Gram-positive organisms and the presence of a pleomorphic Gram-variable rod in long chains clustered about the starch grains. Finally, Hungate et al. (1952), studying the effect of grain in excess to sheep, found an increase in the concentration of Streptococcus bovis and Gram-positive rods, probably lactobacilli, and presumed the streptococci to be most responsible for the acute indigestion induced.

\section{MATERIALS AND METHODS}

Commercial wheaten starch has been used for the feeding experiments. The starch was given as a suspension approximately in its own weight of water. For the rest, the experimental and examining procedure has been as described in the previous paper (1960).

\section{RESULTS}

Experiment 1. As will appear from Table 1 the dosing of starch started with $100 \mathrm{~g}$. and the daily doses given were increased by the same amount until at daily dose of $900 \mathrm{~g}$. was reached. Since microscopic examination of the rumen contents $24 \mathrm{hrs}$ after the addition of $900 \mathrm{~g}$. disclosed liberal amounts of starch still present, the very last dose was reduced to $500 \mathrm{~g}$. In the same table are summarized results obtained during the experiment and some of the data are represented in Fig. 1. All data listed refer to 0-hour samples, i.e. rumen fluid withdrawn just prior to the daily administration of starch or at the same hour in the pre-feeding period. 
In general, the microbial composition, $\mathrm{pH}$ and physical properties of the rumen fluid in the preliminary period were such as are usually found on a hay diet. The number of protozoa amounted to about 50 per field of view $(\times 50)$ and of yeast-like cells some hundreds $(\times 450)$. The yeast-like cells as well as the small oligotrich ciliates were mainly found negative to iodine, whereas the other protozoa presented partly positive iodine reaction. The bacterial population consisted of a predominating Gram-negative flora with a few Gram-positive cocci and scarcely any Gram-positive rods. Further, iodophilic bacteria seemed to be few. The cultures gave colony counts of streptococci and cellulolytic bacteria in the range $10^{6}-10^{7}$ per ml. rumen fluid, whereas Gram-positive rods were found in numbers never exceeding $10^{3}$ per $\mathrm{ml}$.

T a b l e 1. Data on the sheep in experiment 1.

\begin{tabular}{|c|c|c|c|c|c|c|c|c|}
\hline \multirow{2}{*}{$\begin{array}{l}\text { Starch } \\
(\mathrm{g})\end{array}$} & \multirow{2}{*}{$\begin{array}{l}\text { Hay } \\
(\mathbf{k g})\end{array}$} & \multirow{2}{*}{$\begin{array}{c}\text { Water } \\
\text { (l) }\end{array}$} & \multirow{2}{*}{$\begin{array}{l}\mathrm{PH} \text { of } \\
\text { rumen }\end{array}$} & \multirow{2}{*}{ Protozoa } & \multirow{2}{*}{$\begin{array}{l}\text { Yeast-like } \\
\text { cells }\end{array}$} & \multicolumn{3}{|c|}{ Number of colonies $/ \mathrm{ml}$ rumen fluic } \\
\hline & & & & & & $\begin{array}{l}\text { Strepto- } \\
\text { cocci }\end{array}$ & $\begin{array}{l}\text { Gram-pos. } \\
\text { rods }\end{array}$ & $\begin{array}{l}\text { Cellulo- } \\
\text { lytic } \\
\text { bacteria }\end{array}$ \\
\hline 0 & 1.0 & 0.7 & 6.9 & $\begin{array}{l}++++ \\
+++++\end{array}$ & +---+ & $5.6 \times 10^{6}$ & $\mathbf{0}$ & $7.0 \times 10^{6}$ \\
\hline $\mathbf{0}$ & 1.6 & 2.0 & $\mathbf{7 . 0}$ & , & , & $1.8 \times 10^{6}$ & 0 & $3.4 \times 10^{6}$ \\
\hline 100 & 1.0 & 2.5 & 7.0 & " & " & $2.8 \times 10^{6}$ & 0 & $1.3 \times 10^{7}$ \\
\hline 200 & 1.2 & 2.8 & & & & & & \\
\hline 300 & 1.0 & 1.8 & 6.9 & " & " & $7.5 \times 10^{6}$ & 0 & $4.3 \times 10^{6}$ \\
\hline 400 & 1.1 & 2.4 & 7.3 & , & , & $5.4 \times 10^{6}$ & $\mathbf{0}$ & $3.5 \times 10^{6}$ \\
\hline 500 & 0.5 & 0.5 & 6.8 & +---+ & , & $3.8 \times 10^{6}$ & $\mathbf{0}$ & $1.2 \times 10^{6}$ \\
\hline 600 & 0.6 & 2.8 & 6.9 & +---+ & +++ & $1.9 \times 10^{6}$ & 0 & $6.0 \times 10^{6}$ \\
\hline 700 & 0.1 & 1.7 & 6.9 & +---+ & $+t+$ & $1.8 \times 10^{6}$ & 0 & $2.5 \times 10^{6}$ \\
\hline 800 & 0.9 & 1.9 & 6.9 & +++++ & $+(+)$ & $1.0 \times 10^{6}$ & 0 & $3.4 \times 10^{7}$ \\
\hline 900 & 0.4 & 1.1 & 6.0 & +---+ & $+(+)$ & $4.0 \times 10^{5}$ & $4.4 \times 10^{6}$ & $5.0 \times 10^{6}$ \\
\hline 500 & 0.1 & 1.2 & 5.3 & $(+)$ & + & $6.0 \times 10^{8}$ & $1.0 \times 10^{4}$ & $1.0 \times 10^{6}$ \\
\hline 0 & 0.1 & 0.9 & 4.2 & 0 & $(+)$ & $7.5 \times 10^{4}$ & $1.4 \times 10^{7}$ & $4.0 \times 10$ \\
\hline 0 & 0.1 & 0.6 & 4.6 & 0 & $(+)$ & $5.0 \times 10^{4}$ & $5.1 \times 10^{7}$ & 0 \\
\hline 0 & 0.2 & 2.0 & 4.6 & 0 & $(+)$ & 0 & $1.6 \times 10^{8}$ & 0 \\
\hline
\end{tabular}
+--+ means unusual great number.

The first seven dosings of starch did not bring forth any notable alterations in culture counts, $\mathrm{pH}$ and gross appearance of the 0-hour samples, although each administration of starch induced a slow and moderate decline in rumen reaction, following the larger doses towards $6.0-5.5$ ten to twelve hours after the feeding. However, direct microscopy of the 0-hour samples dis- 
closed some changes in the rumen population. The most conspicuous finding was the appearance of a vast flora of long curled chains consisting of Gram-negative or variable rods. The cells in each chain were closely packed and especially in Gram-stained films it was frequently difficult to distinguish single cells, thus the chains giving the appearance of long filaments. In samples containing starch the organism tended to be clustered about starch grains and a positive reaction to iodine could be observed. The size of each cell in Gram-stained films was approximately $1.0-1.3 \times 2-3$ microns and the length of the chains varied from about 10 to some hundred microns. The organism appeared in the rumen the third day of the feeding period, increased immensely in number during the following 3 to 4 days after which it disappeared again. In the cultures no growth of the organism could be observed.

In addition to the organism mentioned above, some other bacteria were evidently multiplying in the rumen during the first week of the experimental period as judged by direct microscopy of the samples. In the first place, large cocci or coccoids occurring singly, in pairs and in short chains and presenting negative or variable reaction to the Gram stain. The size of the cells was approximately $1.6-2.2$ microns; they tended to be attached to starch grains and gave positive reaction to iodine. Secondly, small rods or coccoids forming festoons about starch granules were also observed during this period. This organism showed negative Gram reaction but was positive to iodine.

The concentration of protozoa increased during the latter part of the feeding period. All kinds of protozoa appeared to be strongly iodophilic, although - until the last two dosings the small oligotrichs were usually found aniodophilic in the 0-hour samples. The large protozoa ingested starch grains in abundance and such engorged cells were frequently found nonmotile in spite of normal or slgihtly lowered rumen reaction. The amount of yeast-like cells did not change notably during the first 5 days of the experimental period but later the concentration began to decrease. The cells were found iodophilic after each administration of starch and in the 0-hour samples too, when the larger doses were reached.

The profound changes in the rumen, leading to an acid indigestion, began to appear after the feeding of $800 \mathrm{~g}$. starch and developed further following the last two dosings. During these 


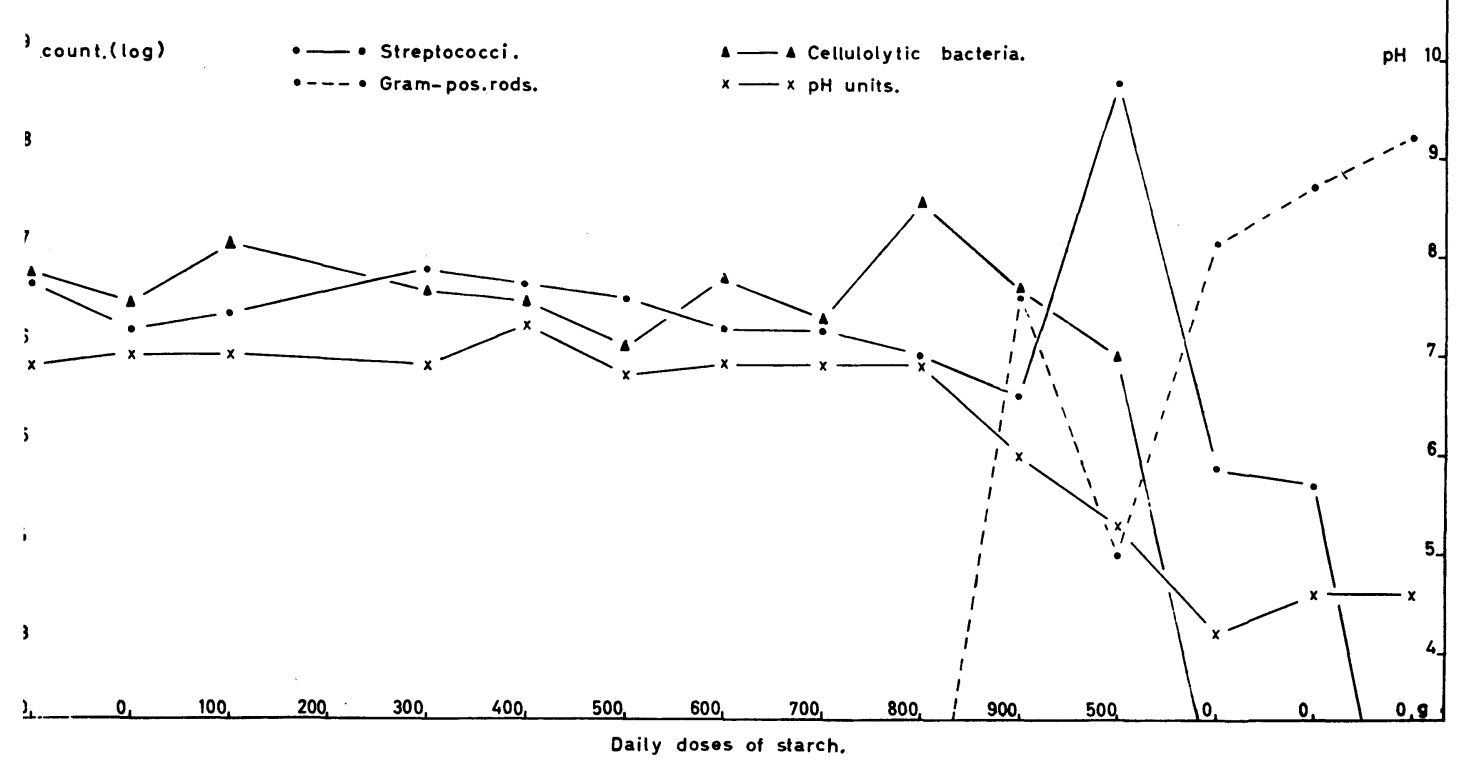

$\mathrm{F}$ i g. 1. Fluctuations in rumen $\mathrm{pH}$ and colony counts in experiment 1.

days a dominating Gram-positive flora of rods and streptococci turned up, the rumen $\mathrm{pH}$ fell from near neutrality to 4.2 and the rumen fluid became greyish brown with a smell reminiscent of sour milk. At the same time the protozoa disappeared entirely from the rumen fluid, only remnants of yeast-like cells were to be seen and a reduction of the original bacterial flora seemed to occur.

In this experiment the Gram-positive rods turned up in the rumen before any rise in the streptococcal flora was noticed. Further, two morphologically different types of rods were found, although they did not appear simultaneously. Thus, the rods observed the first day were of uniform size, $0.6-0.8 \times 1.5-2.5$ microns, straight or slightly curved, and frequently with swollen ends. Chains were never observed, but the rods tended to form small clusters and were often found about disintegrating starch grains. They were mostly distinct Gram-positive, although cells exhibiting uneven and granular staining were not rarely seen and could easily be mistaken for cocci. - The next day another rod more like that regularly found in the previous experiments with sucrose and lactose, did also appear in the rumen. It proved 
to be a slender rod with rounded ends, $0.6-0.7 \times 2-6$ microns, occurring singly or more rarely in short chains without any tendency to form clusters and the reaction to the Gram stain was distinctly positive. The concentration of Gram-positive rods in the rumen increased during the following 2-3 days, the first type observed apparently outnumbering the latter one and frequently occurring in clusters of $100-200$ cells about remnants of starch grains. At the same time the amount of Gram-positive cocci which had shown a transient rise, seemed to be decreasing again. Further, a great number of epithelial cells were observed in the rumen fluid during the last days of the experiment.

The culture counts of streptococci and Gram-positive rods seemed to be in fairly good agreement with the fluctuations observed by direct microscopy of rumen samples except for the colony count of rods obtained the second day after the establisment of these bacteria in the rumen. Obviously, the fall in the culture count this day was in disagreement with the density of Gram-positive rods in the rumen and was most likely due to the fact that the rod first observed failed to grow. The cultures on the other days revealed that this rod grew with small colonies and it proved to be strictly anaerobic.

Microscopic examination of the two different types of colonies growing in the cultures disclosed rods morphologically resembling those seen in the rumen fluid. Besides club forms the one rod type occasionally presented branched cells.

After having shown a hundred-fold increase the streptococcal colony count decreased markedly when rumen $\mathrm{pH}$ fell to about 4.5 and cessation of growth occurred when the reaction of the rumen remained at this level for a couple of days.

The colony count of cellulolytic bacteria remained within the normal range as long as the rumen reaction was found at a normal level and even when the $\mathrm{pH}$ had fallen to 5.3 the growth was not notably depressed. At higher acidity, however, cessation of growth occurred.

No treatment of the induced indigestion was instituted in the present case and examination of the rumen fluid was continued during the convalescence. Four to five days after discontinuing the starch feeding the rumen $\mathrm{pH}$ reached pre-feeding values and the physical properties of the rumen fluid seemed to be normal. However, the number of Gram-positive rods still remained at a high level and only a few Gram-positive cocci and no protozoa 
or yeast-like cells were to be seen. Later on the rod population decreased, whereas the streptococcal concentration rose to above pre-feeding level; the culture counts of rods and streptococci at 8 and 14 days were of the order of magnitude $10^{5}$ and $10^{8}, 10^{4}$ and $10^{8}$, respectively. In the course of the following fortnight the bacterial picture of the rumen was apparently approaching that normally seen on a hay diet. At the end of this period the yeastlike cells began to reappear in the rumen, whereas protozoa could still not be observed.

The persistence of starch in the rumen during the experimental period was registered by microscopic examination of samples stained with iodine. It appeared that the concentration of starch grains decreased rather rapidly during the hours following each feeding and any starch could hardly be seen in the 0-hour samples during the first 7 days of the feeding period. On the other hand, after the last dosing the rumen contents were found rich in starch grains for about 4 days. Further, there seemed to be close correlation between the persistence of starch and the fluctuations in rumen $\mathrm{pH}$.

Experiment 2. The dosing of starch started at a higher level and the daily amounts given were increased more rapidly than in the former experiment. In Table 2 are listed the dosing and

T a b l e 2. Data on the sheep in experiment 2 .

\begin{tabular}{|c|c|c|c|c|c|c|c|c|}
\hline \multirow{2}{*}{$\begin{array}{l}\text { Starch } \\
\text { (g) }\end{array}$} & \multirow{2}{*}{$\underset{(\mathbf{k g})}{\text { Hay }}$} & \multirow{2}{*}{$\begin{array}{l}\text { Water } \\
\text { (l) }\end{array}$} & \multirow{2}{*}{$\begin{array}{l}\mathrm{pH} \text { of } \\
\text { rumen }\end{array}$} & \multirow{2}{*}{ Protozoa } & \multirow{2}{*}{$\begin{array}{l}\text { Yeast-like } \\
\text { cells }\end{array}$} & \multicolumn{3}{|c|}{ Number of colonies/ml rumen fluid } \\
\hline & & & & & & $\begin{array}{l}\text { Strepto- } \\
\text { cocci }\end{array}$ & $\begin{array}{l}\text { Gram-pos. } \\
\text { rods }\end{array}$ & $\begin{array}{c}\text { Cellulo- } \\
\text { lytic } \\
\text { bacteria }\end{array}$ \\
\hline $\mathbf{0}$ & 1.5 & 2.4 & 6.4 & $\begin{array}{l}+++++ \\
+++++\end{array}$ & +---+ & $1.1 \times 10^{7}$ & 0 & $1.9 \times 10^{6}$ \\
\hline 300 & 1.9 & 4.0 & 6.7 & , & " & $8.0 \times 10^{6}$ & $\mathbf{0}$ & $3.0 \times 10^{6}$ \\
\hline 600 & 1.6 & 2.3 & 6.5 & , & ” & $3.0 \times 10^{6}$ & $\mathbf{0}$ & $2.5 \times 10^{6}$ \\
\hline 900 & 0.7 & 3.0 & 6.7 & 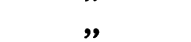 & 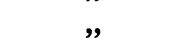 & $3.3 \times 10^{6}$ & $\mathbf{0}$ & $1.0 \times 10^{6}$ \\
\hline 1200 & 0.8 & 2.2 & 6.6 & , & ” & $1.4 \times 10^{6}$ & 0 & $1.7 \times 10^{6}$ \\
\hline 1500 & 0.2 & 2.5 & 6.7 & " & $"$ & $1.0 \times 10^{6}$ & 0 & $1.5 \times 10^{6}$ \\
\hline 0 & 0.3 & 0.6 & 4.3 & ++ & $"$ & $2.4 \times 10^{6}$ & $8.5 \times 10^{8}$ & o \\
\hline$\theta$ & 0 & 0.2 & 4.8 & $(+)$ & $(+)$ & 0 & $2.8 \times 10^{9}$ & 0 \\
\hline 0 & 0 & 1.2 & 5.0 & $(+)$ & $(+)$ & 0 & $2.0 \times 10^{8}$ & 0 \\
\hline 0 & 0 & 1.2 & 6.4 & 0 & $(+)$ & 0 & $2.5 \times 10^{8}$ & $2.3 \times 10^{5}$ \\
\hline 0 & 1.1 & 5.0 & 6.4 & $(+)$ & 0 & $3.5 \times 10^{5}$ & $5.6 \times 10^{7}$ & $4.0 \times 10^{5}$ \\
\hline 0 & 0.9 & 4.9 & 7.0 & ++ & 0 & $2.5 \times 10^{5}$ & $6.0 \times 10^{6}$ & $1.0 \times 10^{6}$ \\
\hline $\mathbf{0}$ & 2.0 & 5.0 & 7.0 & +---+ & 0 & $1.0 \times 10^{6}$ & 0 & $1.0 \times 10^{6}$ \\
\hline
\end{tabular}


results obtained in this experiment. All data refer to 0-hour samples withdrawn on successive days with the exception of the last three specimens which were sampled at intervals of 3,5 and 6 days, respectively. Thus, the very last sample examined was withdrawn 18 days after the starch feeding was discontinued.

Direct microscopy of the rumen fluid as well as the culture counts indicated that the microbial composition of the rumen in the pre-feeding period was similar to that found prior to the former experiment.

Except for a rise in the concentration of large cocci or coccoids resembling those encountered in the previous experiment, no significant alterations in the rumen fluid could be observed during the first four days of the feeding period. Thus, the $\mathrm{pH}$ and colony counts of streptococci and cellulolytic bacteria varied within narrow limits and the culture counts of Gram-positive rods did not exceed $10^{3}$ per ml. rumen fluid. The amount of protozoa and yeast-like cells did not show any marked fluctuation, but exhibited similar variations in the iodine reaction as noted previously, although the yeast-like cells were usually found aniodophilic. Further, the fall in rumen $\mathrm{pH}$ following each introduction of starch was moderate and $1200 \mathrm{~g}$. caused less decline than the preceding doses.

On the other hand, the addition of $1500 \mathrm{~g}$. starch induced a rapid and profound change in the rumen contents associated with an acute indigestion. In the course of $24 \mathrm{hrs}$. the reaction fell from near neutrality to 4.3 and the physical properties of the rumen fluid underwent similar changes as observed earlier. The protozoal fauna was markedly reduced, whereas the yeastlike cells were present as before, but now strongly positive to iodine. The bacterial picture was completely dominated by Gram-positive rods resembling those found in experiment 1. Any rise in the concentration of Gram-positive cocci could not be observed but the large coccoids had apparently increased further in number. Obviously, the rods had been multiplying very rapidly as no increase was observed $15 \mathrm{hrs}$. earlier and now the culture count approached $10^{9}$ per ml. rumen fluid. The colony count of streptococci was still within the same range as previously, whereas no cellulose-splitting bacteria were growing in the cultures. In addition to rods and streptococci the cultures this day gave growth to large Gram-negative or variable cocci resembling 


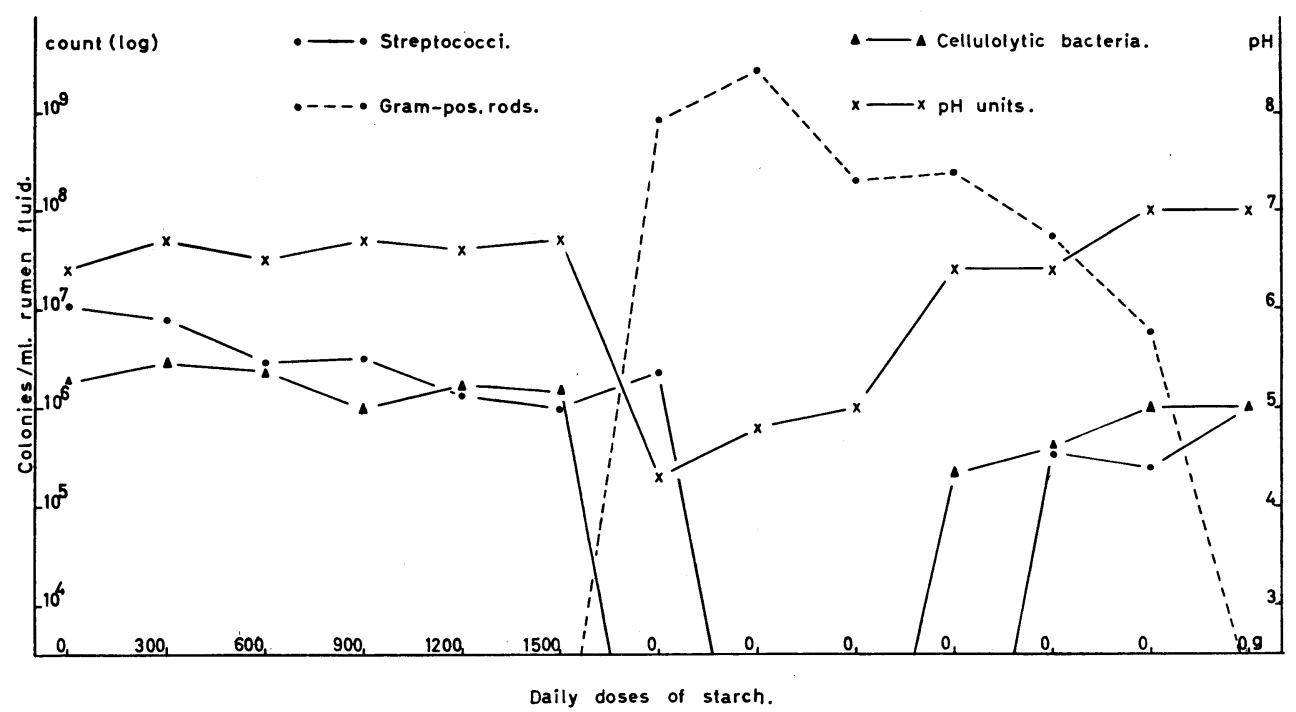

F i g. 2. Fluctuations in rumen $\mathbf{p H}$ and colony counts in experiment 2.

those seen in the rumen. This organism appeared to grow best in the CYG-medium and presented large lenticular colonies to the number of $10^{6}-10^{7}$ per $\mathrm{ml}$. rumen fluid.

The Gram-positive rods presented two distinctly different colony forms in the CYG-medium, viz. lens-shaped compact and somewhat smaller round, crenated colonies. The two colony types proved to be consisting of morphologically different rods resembling those found in the first experiment.

The sample withdrawn $48 \mathrm{hrs}$. after the last feeding disclosed a still more altered rumen population. Only remnants of protozoa and yeast-like cells were found and the Gram-negative bacterial flora originally present seemed to be strongly reduced. The cultures gave no growth to streptococci and the colony count of rods showed a further increase. In addition, epithelial cells were appearing in the rumen fluid this day.

In this case, too, the experimental animal recovered spontaneously and the examinations were continued until the rumen population was approaching the normal state.

The cellulolytic bacteria reappeared in the cultures as soon as the rumen reaction rose to pre-feeding level, although about one week elapsed before normal colony counts were obtained. The streptococci, however, did not reappear in the cultures as 
quickly as the former did and a somewhat longer time elapsed before the counts increased to normal level.

The colony counts of the large Gram-negative coccoids were found in the range $10^{5}-10^{7}$ for 4 days after discontinued feeding, and then they disappeared from the cultures. Finally, the culture counts of Gram-positive rods passed the peak the second day after the last addition of starch, decreased slowly in the course of 10 days to the range $10^{6}-10^{7}$ and further to pre-feeding level during the following week.

No protozoa were found in the samples withdrawn at 4 and 6 days after the last feeding; later on they reappeared and increased gradually in numbers until a concentration similar to that observed in the preliminary period was reached in the last sample examined. On the contrary, the yeast-like cells which disappeared from the rumen about a week after the last introduction of starch, were later not observed in the samples.

Concerning the persistence of starch in the rumen only insignificant amounts were found $24 \mathrm{hrs}$. after the addition of 1200 g., whereas following the very last feeding, liberal quantities persisted for $3-4$ days. Further, the rumen contents remained strongly acid as long as starch was present after which the reaction rather quickly rose to normal values.

Experiment 3. After a lapse of 4 months the former experiment was repeated, using the same experimental animal. In this case, the microbial studies were confined to microscopical examination of the rumen fluid.

On the whole, the feeding of starch led to similar alterations in the rumen as those encountered in the previous experiment. However, one striking difference observed was the development of a huge flora of Gram-negative or variable rods occurring in long chains. Judged by the morphology and reaction to the Gram and iodine stains the organism seemed to be identical to that found in experiment 1 . It started multiplying in the rumen the second day of the feeding period and increased strongly in numbers during the following days, forming a net-work of curled chains up to about 200 microns in length. The organism showed a lower concentration after the last addition of starch and later it seemed to disappear from the samples.

In accordance with the former experiment no rise in the streptococcal flora seemed to occur. Succeeding the last ad- 
ministration of starch Gram-positive rods began to multiply and increased later in numbers. The forth and fifth day after discontinued feeding the rumen fluid presented a nearly pure culture of Gram-positive rods since protozoa, yeast-like cells, streptococci and the rest of the normal flora seemed to be completely destroyed or present in very reduced numbers. However, in the course of the next $24 \mathrm{hrs}$. a profound change in the bacterial picture did obviously take place as the following sample revealed a dense Gram-negative flora consisting of small cocci and rods, whereas the concentration of Gram-positive rods had decreased immensely. Two days later, i.e. 8 days after discontinued feeding, the bacterial flora of the rumen seemed to be approaching the pre-feeding state, although some more Gram-positive rods than normally were still present. At that time the protozoa and yeastlike cells had not reappeared in the rumen but the animal had recovered from its acute indigestion and showed normal appetite.

The Gram-positive rods developing during the experiment were morphologically like those encountered in the preceding experiments. Simultaneously with the appearance of the rods in the rumen the reaction fell abruptly from normal level to 4.5 and after having remained within the range $4.5-4.8$ for 3 days the $\mathrm{pH}$ rose rapidly to initial values. The persistence of starch in the rumen seemed to be slightly less than 3 days and thus somewhat shorter than in the previous experiment.

Identification of the Gram-positive ruminal flora. A number of streptococci and Gram-positive rods have been isolated and classified. With the exception of one single strain all streptococcal isolates proved to be amylolytic. All Gram-positive rods studied were found to be lactobacilli, the majority of which were fermenting starch very rapidly. A detailed description of the isolates will be given in a subsequent paper.

\section{CLINICAL OBSERVATIONS}

The clinical syndrome associated with the indigestion induced in the present experiments was found similar to that observed when sucrose or lactose was given in excess, although the animals were never so severely affected that any treatment was considered necessary. Apart from a lowered intake of hay and slightly changed faeces consistency, no significant alteration in 
the well-being of the animals was noticed until the profound change in the rumen contents occurred. The acute indigestion was characterized by a moderate rise in temperature, anorexia, decreased motility or stasis of the rumen, cessation of rumination, a slight diarrhoea with greyish faeces and increasing dullness and depression leading to recumbency. In one case the animal exhibited pronounced lameness which, however, subsided in a couple of days. The rumen contents did not become nearly as watery as usually observed in the sugar experiments, nor were symptoms of cerebral disturbances present.

Examination of the urine disclosed a significant fall in $\mathrm{pH}$ at a very early stage. Thus, in experiment 2 the first dose of starch induced a drop in urine $\mathrm{pH}$ from 8.0 to 7.1 and the next dosing was followed by a further decline to 6.0, although the fluctuations in rumen $\mathrm{pH}$ at that time were insignificant. Simultaneously with the final acidifying of the rumen the urine $\mathrm{pH}$ fell to about 5.0 but approached neutrality again soon after the rumen reaction rose to normal level. In addition, proteinuria was observed in connection to the indigestion.

Microscopic examination of the faeces during the feeding period revealed a large concentration of starch grains. The faeces was further found rich in iodophilic cocci and rods which was in contrast to the findings in the pre-feeding period. The Gramstain showed that the faecal flora mainly consisted of Gramnegative bacteria. During the last days of the experiments the $\mathrm{pH}$ of the faeces was found in the range $4.5-5.0$ in contrast to a reaction about 8.0 in the preliminary period.

The decline in blood $\mathrm{pH}$ associated with the indigestion was not very marked, the lowest value measured was 7.3 (7.6 before the feeding period).

Chemical analyses on rumen and blood disclosed only minor variations in the lactic acid content until the lactobacilli turned up which, on the other hand, caused a sharp rise, although never reaching the high levels usually found in the sugar experiments. The concentration of serum calcium and magnesium showed a slow progressive drop during the experimental periods but without reaching actually pathological values. (Extensive chemical analyses have been carried out at the Department of Biochemistry of this College during these experiments and will be published separately). 


\section{DISCUSSION AND CONCLUSION}

It has appeared from the present experiments that starch in excess to hay-fed sheep leads to an acute acid indigestion associated with profound alterations in the rumen. In many respects the changes induced by starch were similar to those obtained when sucrose or lactose was given under corresponding conditions. Thus, a common feature in all experiments conducted has been the abrupt development of a vast flora of lactobacilli when the carbohydrates have been given for some time. Evidently, just this change in the rumen flora is the most important of the microbial alterations occurring because it leads to a huge accumulation of lactic acid in the rumen with destruction or depression of the original rumen population. The assumption that the high acidity is the main detrimental factor influencing the rumen population is supported by the observations that, in spite of a persistent lactobacillosis, the normal bacterial flora is reappearing quickly when normal rumen reaction is restored. However, some of the rumen inhabitants, principally the protozoa and yeast-like cells, are apparently more sensitive to acid conditions than the others since a considerable time must usually elapse before they reappear in the rumen. It is further reasonable to assume that the frequent occurrence of epithelial cells in the acid rumen contents, and judged to be a symptom of acute rumenitis, is also a result of the prolonged high acidity induced by the lactobacilli.

On the other hand, the changes in the bacterial flora induced by starch were in some respects different from those occurring in the sugar experiments. For one thing, when sugar was given a temporary rise in the streptococcal flora did regularly precede the multiplication of lactobacilli. In the starch experiments, however, this regularity was not observed. In the only case where an increase in the streptococcal population was noticed, this occurred after the lactobacilli had turned up in the rumen, whereas in the two other experiments no rise in the streptococcal flora was observed at all. This fact is rather surprising since all except one of the streptococci isolated from the starch-fed animals were fermenting starch very readily in vitro and proved to be Streptococcus bovis which is considered to be the chief rumen bacterium concerned with the fermentation of starch. The interpretation may probably be that the starch-rich food in the present experiments rendered the rumen contents more suitable for the 
lactobacilli than for the streptococci, thus encouraging the former to multiply more rapidly than the latter and, when established in the rumen, the lactobacilli hindered any streptococcal growth at all. In this connection it may be worth mentioning that it seems to appear from the experiments of Hungate et al. (1952), that a significant rise in the streptococcal flora did not invariably occur when grain was given in excess to sheep.

It was further evident from the present experiments that the feeding of starch encouraged the presence of other types of lactobacilli than the sugars did. Amylolytic lactobacilli were very rarely encountered in the sugar experiments, whereas the preponderance of lactobacilli developing when starch was fed were attacking starch very readily. In addition, the starch-splitting lactobacilli were apparently those first turning up in the rumen in each experiment, whereas the non-amylolytic species appeared later.

Other kinds of bacteria rarely seen or observed only in moderate amounts in the sugar experiments were found in abundance when starch was being fed. The one type was the Gramnegative or variable rod occurring in long chains clustered about starch grains. The organism did not grow in the cultures and could, therefore, not be submitted to further studies, but it seems probable that the bacterium was concerned with the breakingdown of starch. The Gram-variable rod in long chains observed by Williams et al. (1953) in the rumen of sheep on a starch-rich diet might possibly be an organism similar to that occurring in the present experiments, but lacking description of its morphology makes a further comparison impossible. More over, to a certain extent the bacterium in question seems to be similar to Organism No. 18 in the illustrated scheme on rumen microorganisms of sheep presented by Moir and Masson (1952).

Large Gram-variable, iodophilic cocci or coccoids were apparently occurring in higher concentrations in the present experiments than in the experiments with sugar. Evidently, this bacterium is identical with Organism No. 27 in the scheme mentioned above.

The fall in rumen $\mathrm{pH}$ after each addition of starch in the period before the lactobacilli turned up appeared to be moderate and no significant amounts of lactic acid accumulated in the rumen. In this respect, the effect of starch was far less than that of sucrose and more like the results obtained when lactose 
was given. However, in agreement with the lactose experiments the urine became acid at a very early stage, indicating an absorption of acid sufficient to influence the acid-base balance.

By comparing the effect on the rumen population of the three different carbohydrates used it will appear that sucrose induced the profound alterations most rapidly, whereas the feeding with lactose and starch had to be continued somewhat longer to get a similar effect. A further comparison between lactose and starch indicates that the former was more effective than the latter, although great variations in the response to lactose were observed. On the other hand, the maximum concentrations of lactic acid in rumen and blood were of the same order of magnitude when sucrose or lactose was fed but markedly lower when starch was given. This difference in the accumulation of lactic acid seemed to be reflected by the well-being of the animals, the starch-fed sheep exhibiting less severe clinical symptoms than the others. It is reasonable to assume that the lower concentrations of lactic acid found in the present experiments were due to a slower fermentation of the starch than of the sugars since bacteria as well as fermentable material were present in abundance.

Concerning the persistence of starch in the rumen it appeared that - except for the largest doses given - all or nearly all starch disappeared within $24 \mathrm{hrs}$. Obviously, this rapid disappearance of the starch from the rumen cannot be accounted for by fermentation only and the examination of faeces revealed that a great proportion of the starch given passed the digestive tract without being fermented. The high acidity of the faeces as well as the altered faecal flora, being different from that found in the rumen, indicates that a part of the starch had been subjected to fermentation on passing the intestine.

In agreement with the observations made in the experiments with lactose there seemed to be some correlation between the intake of water and the persistence of starch in the rumen. Thus, the average daily intake of water during the feeding period in the two identical experiments 2 and 3 was 2.4 and 5.0 liters, respectively, and in the latter case a shorter persistence was found. Further, still in agreement with previous findings with lactose, the starch persisted far longer in the rumen when the fermentation increased, obviously due to slowed rumen function or rumen stasis. 


\section{Acknowledgements.}

The author wishes to express his gratitude to The Agricultural Research Council of Norway for financial aid in support of these studies and to Mrs. Joy Gjoennes for technical assistance.

\section{REFERENCES}

Gall, L. S., and Huhtanen, C. N.: J. Dairy Sci. 1951, 34, 353.

Hungate, R. E., Dougherty, R. W., Bryant, M. P., and Cello, R. M.: Cornell Vet. 1952, 42, 423.

Krogh, N.: Acta vet. scand. 1959, 1, 74.

Krogh, N.: Acta vet. scand. 1960, 1, 383.

Masson, M. J.: Brit. J. Nutr. 1950, 4, viii.

Moir, R. J., and Masson, M. J.: J. Path. Bact. 1952, 64, 343.

Pounden, W. D., and Hibbs, J. W.: J. Dairy Sci. 1948, 31, 1051.

Williams, V. J., Nottle, M. C., Moir, R. J., and Underwood, E. J.: Aust. J. biol. Sci. 1953, 6, 142.

\section{SUMMARY}

The feeding of starch in excess to hay-fed sheep led to an acute. acid indigestion with profound alterations in the microbial composition of the rumen.

Various changes in the bacterial flora occurred during the feeding periods, but the acute indigestion was related to the development of a rumen lactobacillosis leading to a pronounced fall in $\mathrm{pH}$ with depression and destruction of the flora and fauna originally present in the rumen.

The increase in the concentration of amylolytic streptococci regularly observed when sucrose or lactose was given in excess did not invariably occur in the starch experiments.

The flora of lactobacilli developing on the high-starch diet differed qualitatively from that obtained when sucrose or lactose was fed.

In general, the tolerance for starch appeared to be higher than for sucrose and lactose.

\section{ZUSAMMENFASSUNG}

Untersuchungen über Änderungen in der mikrobiellen Zusammensetzung des Pansensaftes beim Schaf beim Zusatz leichtverdaulicher Kohlehydrate zum Futter. III. Stärke.

Verabreichung von Stärke im Ueberschuss an Schafe bei Heufütterung bewirkte akute saure Indigestion mit ausgeprägten Veränderungen in der mikrobiellen Zusammensetzung des Pansensaftes.

Während der Fütterungszeit wurden verschiedene Änderungen in der Bakterienflora wahrgenommen, aber die akute Indigestion entstand im Anschluss an die Entwicklung einer Lactobacillose im Pansen mit ausgesprochenem Sinken des pH-Wertes und Depression oder Destruktion der normalen Flora und Fauna des Pansens. 
Eine Zunahme der Menge amylolytischer Streptokokken, die bei Zuschuss von Rohrzucker oder Milchzucker stets wahrgenommen wurde, trat bei Verabreichung von Stärke nicht regelmässig ein.

Die Milchsäureflora, die sich in den Stärkeversuchen entwickelt hatte, wich qualitativ von derjenigen ab, welche sich bei Ueberfütterung mit Zucker vorfand.

Im allgemeinen war die Toleranz gegenüber Stärke grösser als für Rohrzucker und Milchzucker.

\section{SAMMENDRAG}

Undersökelser over endringer i vomsaftens mikrobielle sammensetning hos sau ved tilskudd av lettfordöyelige kullhydrater til foret.

III. Stivelse.

Stivelse i overskudd til sauer på höyforing förte til akutt sur indigestion med uttalte endringer $i$ vomsaftens mikrobielle sammensetning.

Det ble iakttatt forskjellige endringer i bakteriefloraen under foringstiden, men den akutte indigestion oppstod i tilslutning til utviklingen av en lactobacillose $i$ vommen med uttalt fall $i \mathrm{pH}$ og depresjon eller destruksjon av vommens normale flora og fauna.

ökning i mengden av amylolytiske streptokokker, som alltid ble iaktatt ved tilskudd av rörsukker eller melkesukker, forekom ikke regelmessig når stivelse ble gitt.

Melkesyrefloraen som utviklet seg under stivelsesforsökene, avvek kvalitativt fra den en fant ved overforing med sukker.

Generelt sett var toleransen overfor stivelse större enn for rörsukker og melkesukker.

(Received October 12. 1960). 